\title{
Making the Political Offence Legal? The Interpretative Role of the Jury in the Belgian Legal Tradition
}

The 1831 Belgian Constitution restored the jury trial for criminal matters, press offences and political offences. The latter was copied from the 1830 French Charte constitutionnelle, but despite the fact that this was a terminological novelty in the western legal tradition, no definition was given. The Belgian constituent did so on purpose, as it enlarged the interpretative role of the jury. In this regard, it was even attributed a double role, the jurors did not only have to judge on the substance of the case, but on the interpretation of the criminal provisions as well, which were often vague in political matters. However, in Belgian legal practice, the judicial authorities soon lost faith in jury trials and a case-law was developed which substantially narrowed the definition of the political offence, which eventually led to a fossilization of the constitutional ideal. Hence, professional magistrates have succeeded in developing a strategic way to avoid a popular judgment in political matters without violating the constitution.

\section{The jury trial for political offences: A key element of the Belgian judicial organisation (1830-31)}

When in the winter of 1830-1831 the Belgian National Congress gathered to draw up a constitution for the freshly born nation state, there was little doubt about the restoration of the jury trial. The participation of laymen in the administration of criminal justice had been introduced in the Southern Netherlands after their annexation by the French regime (1795-1815), but this lay institution was soon abolished by the Dutch king William when the Southern and the Northern Netherlands were joined together after the fall of Napoleon. ${ }^{1}$ Jury trial only had been a short-lived phenomenon in the Northern Neth-

\footnotetext{
1 The trial jury was abolished in the Northern Netherlands by the Decree of 11.12.1813 and in the Southern Netherlands by the Decree of 6.11.1814. On this abolishment, see: BOSSERS, Welk eene natie 86-87; CORNEGOOR, Opmerkingen over de jury 196-201.
}

erlands and received little support in a country dominated by a 'regent culture' with a long tradition of respect for professional expertise. ${ }^{2}$ However, during the United Kingdom of the Netherlands (1815-1830), the debate on the jury trial soon came to the fore again. When at the end of the 1820s Southern opposition became fiercer and several leading journalists were prosecuted and sentenced by professional judges for their criticism, the restoration of the trial jury was claimed in numerous articles, brochures and petitions. However, whether the discussion on the reform of the criminal procedure brought up the matter in the spring of 1829, the Hague never yielded to the Southern claims. ${ }^{3}$

\footnotetext{
2 TE VELDE, Van Regentenmentaliteit tot populisme $29-52$.

${ }^{3}$ At the occasion of the reform of the napoleonic code of criminal procedure, the president of the Hague lower chamber asked the assembly by means of three preliminary questions whether a general restoration of the trial jury was needed, whether a restoration of the trial jury only for political offences and press
} 
When in the summer of 1830 the French Trois Glorieuses made an end to the authoritative Bourbon-regime and the July-Monarchy was established on a sound constitutional basis, this French example inspired a group of young bourgeois in the Southern Netherlands to rise in revolt against the Dutch regime. After a brief struggle, the independence of the Belgian nation state was declared and a new constitution was drafted. Therefore, the Belgian Constitution of 7 February 1831 stated that a jury had to be sworn in in criminal matters, as well as for press offences and political offences, ${ }^{4}$ a provision which clearly revealed the influence of the French Constitutional Charter of 14 August 1830.5

The restoration of the trial jury was not merely a reaction against the former Dutch regime, but it was fundamentally inspired by French Restoration liberalism. This was definitely the case when the political offence (délit politique) was concerned, since this was a terminological novelty in the western legal tradition. The political

offences was needed and whether the jury d'accusation had to be restored. All questions received a negative answer. The voting behaviour clearly revealed the dissension of the northern and the southern representatives. See: NoORDZIEK, Geschiedenis der beraadslagingen 1-254 and 492-507.

${ }^{4}$ Art. 98 (nowadays Art. 150) The constitutional provision is still in force, but since 1999, a jury has no longer to be sworn in for press offences inspired by racism or xenophobia. Art. 96 (nowadays Art. 148), the Jury Decree of 19.7.1831 and the Press Decree of 2. 7. 1831 provided in several additional procedural guarantees for press offenders and political offenders. ${ }^{5}$ In France, the trial jury was never abolished, but Art. $69,1^{\circ}$ of the Charter of 14.8 .1830 stated that the jury procedure had to be applied to press offences and political offences as well. This of the former liberal opposition, who successfully, as the French law of 26. 5. 1819 had referred all offences committed by the press or other means of publication to the courts of assizes. However, due to changed political circumstances, the French law of 25.3.1822 had returned jurisdiction over press offences to the professional misdemeanor courts. offence represented a different conception of political crime, an idea which had been developed by the eighteenth-century Neapolitan philosopher Gaetano Filangieri, whose works had been translated into French by the leading thinker Benjamin Constant. ${ }^{6}$ The ideas of the latter exercised great influence on the liberals of the Southern Netherlands. ${ }^{7}$ Filangieri and his epigones argued that the political offence was essentially different from all other offences, because it was not just a breach of the legal order. It was an act of political criticism, an attack against the fundamental elements of state order, a threat to its institutional framework. ${ }^{8}$ In this regard, the concept of the political offence was a key element of the political thought of the founding fathers of the Belgian nation state too. Although classic institutional guarantees such as parliamentary representation and the separation of powers were considered crucial to avoid despotism and other forms of abuse of power, there was a pressing need for extra-institutional safety valves. In this regard, the allowance of legitimate acts of criticism and protest was vital for the functioning of the political institutions. Therefore, the press offence was somehow the constitutional twin brother of the political offence, as it was considered an illegitimate act of criticism against the political authority as well.

Despite the clear theoretical conception of this new notion, there was no legal elaboration of the political offence. Unlike in France, the constitutional assembly did not determine which offences were political and should be tried by jury, nor did it indicate what circumstances turned an ordinary criminal offence into a political one. ${ }^{9}$

\footnotetext{
${ }^{6}$ DREYFUS, Généalogie du délit politique 165-202.

${ }^{7}$ DelBeCKe, Verdedigers van het eigen vrije woord 142-158.

${ }^{8}$ DREYFUS, Généalogie du délit politique, 257.

9 The French law of 8 October 1830 drew up a nondelimiting list of political offences, but the Belgian legislator did not follow this example, probably be-
} 
This lack of a definition was probably not merely a matter of negligence. Since all definitions risked to be interpreted in a tendentious way by the authorities, which were naturally part of the political order itself, the absence of a clear-cut description in controversial political matters was regarded rather a guarantee than a problem: omnis definitio periculosa. Moreover, since the political offence was essentially related to political matters, it was impossible to put it down in a fixed legal text or to draw up a delimiting list of offences. ${ }^{10}$ Obviously, this idea was not an academic consideration, as the founding fathers already had witnessed a turbulent Sattelzeit with subsequent revolutions and several regime changes. Hence, whether the political offence was a key element of the institutional thought of the Belgian National Congress, its specific elaboration and its development were largely referred to the subsequent legal practice.

\section{A double role for the jury in political affairs?}

When considering the special constitutional position of the political offence (and press offences), the jurisdiction of the popular jury seemed self-evident in these matters. Generally, scholars consider the jury trial a 'negative' guarantee, since its establishment was predominantly inspired by a profound mistrust towards professional judges. The judgment on the legitimacy of these acts of political criticism could not be attributed to professional judges, as their position was inextricably bound up with the institutional system itself and therefore, they lacked independence. Obviously, this was an important

cause such discussions would reveal the dissension between catholics and liberals.

${ }^{10}$ See in this regard for instance the comments in the French parliament on the French law of 8.10.1830: Dreyfus, Généalogie du délit politique 165-176. argument in the eyes of the architects of the Belgian constitution, since professional judges were appointed by the government and therefore, their independence was questionable. Besides, since political matters were generally controversial affairs, a verdict in these matters could stir up emotions and undermine the authority of the judiciary. ${ }^{11}$ In this regard, the jurisdiction of a trial jury, composed of twelve members of society was a better institution to decide whether these acts of criticism against the public authorities were legitimate or not. In times of revolution and shifting regimes, the presence of a panel of citizens who were not affiliated to the institutional framework was considered the ultimate guarantee for a fair trial for those who claimed to have struggled against despotism for the benefit of the people.

Moreover, "pour bien apprécier ces délits, il faut être répandu dans la société, la vie rétirée du juge ne lui permettant pas de bien connaître l'opinion".12 The restoration of the jury for political offences was therefore a matter of integrating non-state justice in the institutional framework of a nation, "un lieu de rencontre entre le pouvoir et la société". 13 Since the political offender was considered an idealist opponent of the regime, a due process was only possible when he was judged by his peers, who were gathered in a panel of twelve men good and true. Hence, the jury was considered the perfect judicial benchmark to judge whether a certain act of opposition or protest was in accordance with public opinion. Only the people itself could judge whether the act was a legitimate act of opposition which had served the interests of the people, or whether it was a reprehensible deed which had to be sentenced. The jury only judged over the substance of the case to pronounce a verdict of guilt or an acquit-

\footnotetext{
${ }^{11}$ DONOVAN, Juries and the transformation of criminal 49-85; SCHNAPPER, Le jury français 184-188.

12 HuYTTENS, Discussions du Congrès national 594.

${ }^{13}$ JAUME, Les libéraux français et le jury criminel 50.
} 
tal. This was particularly important for political offences, since their legitimacy was determined by different circumstances and numerous nuances.

The trial jury was regarded the perfect benchmark of public opinion because the composition of the jury was renewed for every session of the Courts of Assizes. ${ }^{14}$ Hence it was an accurate reflection of the most recent evolutions in the political ideas that moved society. Civil society developed continuously and changes in political thought and public opinion were often abrupt. Hence, it was indispensable in political affairs that the jury reflected the pulse of society. In this regard, the famous French liberal Pierre-Paul Royer-Collard had argued that in these matters it was indispensable "que le fait reste en la puissance de la société, qui ne le fera parvenir au juge qu'après l'avoir constaté elle-même dans son intérêt, par des arbitres tirés de son sein, qui soient sa parfaite image, et qui, pour ne cesser jamais de l'être comme le fait lui-même". ${ }^{15}$ As a consequence, the selection procedure of independent jurors was extremely important. Therefore, they were not appointed by the administration, but randomly selected among the members of the civil upper class. ${ }^{16}$ The elitist composition of the jury was even considered an additional guarantee for the independence of this institution. The prevailing idea was that the safeguarded by those people who took a great deal of interest in the stability of the institutions. Besides, in times of great political controversy, these people would be less swayed by the issues of the day. Hence, the judgment of political offences and press offences

\footnotetext{
${ }^{14}$ Art. 1 Jury Decree of 19. 7. 1831.

${ }^{15}$ Quoted in JAUME, Les libéraux français et le jury criminel 51.

16 The selection of jurors was no longer attributed to the administration as it had been done by the Napoleonic code of criminal procedure, but by selection by lot. See: Art. 2-6 Belgian Jury Decree of 19. 7. 1831.
}

was evidently attributed to "un jury des notables". 17

It seems that in political matters the jury was awarded an additional role, which surmounted the mere judgment on the facts. When it came to political offences and press offences, they were hard to define and therefore, legal provisions were often put in rather loose terms, offering a large margin of appreciation. Attacking the authority of the law, offending the king, provoking a civil war, plotting against the state, ... Since it was very difficult to grasp these offences within the limits of a settled text, large formulations were inevitable. However, as these large descriptions could include numerous acts of criticism and opposition, there was a real risk that in turbulent political times, malevolent judicial authorities could abuse these large margins to silence legitimate acts of opposition. In the opinion of the Belgian National Congress, this was probably not a merely theoretical consideration, when bearing in mind that the prosecution of the opposition press during the United Kingdom of the Netherlands had been based upon the very large legal grounds offered by some Dutch occasional laws. ${ }^{18}$ In this regard, the jury trial offered an additional guarantee, as the legal provisions would be interpreted in a way that was in accordance with the ideas of public opinion. By doing so, the jury did not merely consider the substance of the political case, but it got involved to a certain extent in the process of the law-making itself. The jury was considered perfectly fit to grasp the evolutionary nature of the political offence in turbulent political times. Hence, the participation of laymen to the admin-

\footnotetext{
17 Obviously, the same ideas prevailed in France: SCHNAPPER, Le jury français 189-193.

18 In this regard, the members of the Belgian National Congress referred to the Dutch decree of 20 April 1815 , which outlawed passing rumours or disturbing public order in very broad terms. HuYTTENS, Discussions du Congrès national 1, 97.
} 
istration of criminal justice implied the attribution of a large margin of appreciation, not only on the question of guilt, but on the interpretation of the criminal provisions as well. Hence, the jury trial was considered a judicial corrective to the rigidity and incapacity of parliamentary law-making in political matters: "Le jury était ainsi convié à préciser le sens de la loi, dans les cas où le sens n'aurait pas été interpreté par la partie publique, d'après les besoins de l'état politique $d u$ pays". 19

\section{The fossilization of a constitutional ideal and the ultimate control of professional magistrates}

Whether the ideal of jury trial was glorified by the Belgian National Congress, nineteenth century legal practice soon revealed several disadvantages, especially in press matters and political matters. Obviously, jury proceedings were often long and expensive, but more fundamental issues were concerned too. Firstly, the outcome of the proceedings in political matters proved to be very unpredictable. There number of acquittals was rather high, especially when the matters of mere political criticism in speeches, brochures or newspaper articles were concerned and no seditious acts had been committed. ${ }^{20}$ Moreover, jury trials generally received a lot of attention; especially in controversial political matters. In this regard, these proceedings often produced a counterproductive effect. When the judicial authorities wanted to prosecute critics and journalists for their subversive opinions, proceedings in the courts of assizes fixed the attention to these messages. Paradoxically, the repression of cer-

\footnotetext{
19 SCHUERMANS, Code de la presse 1, 255.

20 DELBECKE, De lange schaduw van de grondwetgever 416-417.
}

tain acts or deeds of opposition implied that attention was drawn to these offences. Obviously, this was the major crux when a certain seditious speech or a critical article was concerned. In this regard, the jury trial was a double-edged sword: when a verdict of guilty was pronounced, there were obviously little problems for the authorities, but in the case of an acquittal, things were different. Political dissidents often regarded the acquittal pronounced by the Court of Assizes as the approval of the whole Belgian society, and used the jury verdict as an argument for the legitimization of their ideology. ${ }^{21}$ These arguments applied to the trials of the challengers and the critics of the nineteenth-century Belgian liberal nation state, such as the orangists or the radical democrats, but they prevailed even more when liberals or catholics were involved. Since these ideological opponents had broken up their coalition after their common enemy, the Dutch king William, had acknowledged the Belgian independence in 1839. From then on, their old rivalry had blazed up again and turned into a fierce and persistent conflict. ${ }^{22}$ In this regard, whether the political motives of the offenders were often very obvious, there was considerable reserve to bring offences which were clearly inspired by the clerical-liberal conflict in front of a jury. As these matters were highly controversial, both a sentence as an acquittal would stir up emotions in Belgian public opinion, since they would treat the catholics or the liberals with contempt. Hence, the judicial authorities were very reluctant to bring these matters in front of a jury, as these cases would enhance the social discord anyhow. ${ }^{23}$

\footnotetext{
${ }^{21}$ DeLBECKE, De lange schaduw van de grondwetgever, 148-151.

22 GubIN, NANDRIN, Het liberale en burgerlijke België 245-371.

${ }^{23}$ DeLBECKE, De lange schaduw van de grondwetgever 181-184.
} 
The obvious solution to avoid further controversy in these matters, was to amend the Belgian constitution and abolish the guarantee of jury trial. However, this was impossible because the glorification of this document and of the legacy of the founding fathers of the Belgian nations state was a key element in the nationalist discourse of the time. ${ }^{24}$ Therefore, the judicial authorities provided an alternative by developing a case-law which substantially narrowed the definition of the political offence. In a series of landmark cases, the Belgian Supreme Court (Cour de Cassation) has developed a very restrictive jurisprudence on the matter. On the one hand, the court discerned the so-called 'pure' political offences, which concerned all immediate attacks on the political order. However, in this regard, both the notions of an immediate attack and the political order were interpreted in a narrow way. On the other hand, the Court discerned the 'relative' political offences. These concerned ordinary criminal offences, which were nevertheless considered political offences since these acts had been inspired by political motives. However, in this regard, the Court argued that an ordinary offence could only be considered a political offence when it created an immediate threat to the political order. As a consequence of this restrictive case-law, the constitutional guarantee of jury trial for political offences has become dead letter in Belgian legal practice. ${ }^{25}$ There are no examples of political offences tried by jury in the Belgian post-war era, a situation which is remarkably similar to the development of the press offence. Hence, the case-law of the Belgian Supreme Court has

\footnotetext{
${ }^{24}$ The 1831 constitution was considered the evident outcome of an age-long tradition of liberties. See in this regard: TOLLEBEEK, Historical Representation and the Nation-State 329-353.

${ }^{25}$ On the development of this case-law: Délit politique 351-390; Wailliez, L'infraction politique 162-205; VANDEPUTTE, Het begrip van het politiek misdrijf 74-96.
}

turned this former key element of the institutional framework into a constitutional fossil. Despite measures to enhance the confidence in the trial jury, such as the participation of the jury in the decision on the sentence ${ }^{26}$ and the democratization of its composition, ${ }^{27}$ the dream of the jury as the ultimate interpreter of the political offence was not to last and a restoration of the jury as an institution of political control

When considering the development of political matters in Belgian legal practice, one must conclude that in 1830-31, the Belgian National Congress has overlooked a crucial element. As a matter of fact, the Belgian constitutional assembly only restored the jury de jugement, the trial jury which had to decide whether a political offender was guilty or not. However, the jury d'accusation was not restored and therefore, the access to the Courts of Assizes entirely remained in the hands of professional judges of the chambre de conseil and the chambre de mise en accusation. These courts judged whether there were sufficient indications to bring the case in front of the jury, but they had to qualify the offence too, deciding whether the alleged offences were political or not. In this regard, their decisions could only be overruled by the Supreme Court, which was obviously composed of professional magistrates too. Even when an exception of incompetence was invoked before the professional judges of the ordinary misdemeanour courts (tribunaux correctionnels), the public prosecutors could appeal, which eventually brought the case before the professional judges of the Supreme Court. Hence, whether the Belgian National Congress regarded the participation of laymen as an essential guarantee for the protection of political offenders, the development of the political offence in Belgian legal practice has been totally controlled by professional judges. Hence,

\footnotetext{
${ }^{26}$ Law of 23. 8. 1919.

${ }^{27}$ Law of 21. 12. 1930.
} 
whether the Belgian national has attributed an important role to the jury in making the political offence legal, the professionals of the judiciary have developed a strategic way to avoid a popular judgment in political matters without violating the constitution.

\section{Korrespondenz:}

Bram Delbecke

Subfaculteit Rechtsgeleerdheid Campus Kortrijk

Etienne Sabbelaan 53, 8500 Kortrijk, Belgium

bram.delbecke@kuleuven-kortrijk.be

\section{Literatur:}

Geert. Bossers, Welk eene natie, die de jurij gehad heft en ze weder afschaft (Delft 1987)

R.J.C. CORNEGOOR, 'Opmerkingen over de jury in Nederland tijdens de Franse inlijving', in: Tijdschrift voor Rechtsgeschiedenis 24 (1956) 196201.

Bram DelBeCKe, De lange schaduw van de grondwetgever. Perswetgeving en persmisdrijven in België, 1831-1914 (Ghent 2012).

Bram DELBECKE, Verdedigers van het eigen vrije woord. Advocaten en de ijver voor de persvrijheid in de Belgische grondwet (1830-31), in: Pro Memorie. Bijdragen tot de rechtsgeschiedenis der Nederlanden 9 (2009) 142-158.

Délit politique, in: Edmond PICARD and Napoleon D'Hoffschmidt (Hgg.) Pandectes belges, Bd. 29: Délégation-Dépot (Brussels 1904) 351-390.
James M. DONOVAN, Juries and the transformation of criminal justice in France in the nineteenth and twentieth centuries (Michigan 2010).

Sophie DREYfus, Généalogie du délit politique (Clermont-Ferrand 2009).

Eliane GuBIN, Jean-Pierre NANDRIN, ‘De constructie van België’, in: Els WitTE u.a. (Hgg.) Nieuwe Geschiedenis van België, 1830-1905 (Tielt 2005) 29238.

Emile HuYTtEns (Hg.) Discussions du Congrès national de Belgique, 5 Bde. (Brussels, 1844-45)

Lucien JAUME, Les libéraux français et le jury criminel, in: The Tocqueville Review 18 (1997) 49-70.

J.J.F. NOORDZIEK, Geschiedenis der beraadslagingen, gevoerd in de Kamers der Staten-Generaal, over het ontwerp Wetboek van Strafvordering en het vraagstuk der jury, 1828-1829 (The Hague 1887).

Bernard SCHNAPPER, 'Le jury français au XIX et XX siècles' in Antonio Padoa Schioppa (Hg.), The Trial Jury in England, France, Germany, 17001900 (Berlin 1987).

Henri Schuermans, Code de la presse ou commentaire du décret du 20 juillet 1831 et des lois complétives de ce décret, 2 Bde. (Brussel 1881).

Jo TOLLEBEEK, Historical Representation and the Nation-State in Romantic Belgium (1830-1850), in: Journal of the History of Ideas 59 (1998) 329-353.

Robert VANDEPUTTE, Het begrip van het politiek misdrijf in het Belgisch recht. (Antwerp 1932).

Henk TE VELDE, Van Regentenmentaliteit tot populisme. Politieke tradities in Nederland (Amsterdam 2010).

Gerald WAILLIEZ, L'infraction politique en droit positif belge (Leuven 1970). 